\title{
IMPACT OF LEARNING AND DEVELOPMENT STRATEGY \\ ON ORGANISATIONAL PERFORMANCE
}

\section{SASMITA NAYAK}

Assistant Professor, MBA Department Gandhi Institute for Technology, Bhubaneswar, India

\begin{abstract}
In today's competitive world, organisations are facing high accelerated rate of competition. Top management of the organisations; understand the importance of Human Resource, for business success and growth, and accordingly, managing learning and development activities of organisation, more strategically. Realizing the importance of people, the modern organisations have started capitalizing the human resource, as an advantage for success of organisation. So, modern organisations take the advantage of human resource, in successful business strategy. The importance of learning and development strategy, on planning, design, implementing and evaluating the training programs, which creates learning organisation and ensures values addition of employees. It is a transformation of learning and development of employees, to enhance performance of organisation.

KEYWORDS: Learning, Development, Strategy, Learning Organisation \& Performance
\end{abstract}

Received: Sep 27, 2017; Accepted: Oct 17, 2017; Published: Jan 19, 2018; Paper Id: IJBMRFEB20183

\section{INTRODUCTION}

Modern business environment is found to be very volatile, mainly due to internationalization of business and economic globalization. The market forces have become ultimate determinants, to shape the business goal which is changing very fast. In such background, the sustenance of the business organisation depends on the people, who can accommodate the change and renew the life of the business from time to time. They are the real asset of an organization, who can take the organizations to a commanding height, by utilizing the resources properly. It is believed that, investment on human resource, benefits the individual, the organization and the society at large. Realizing the importance of people, the modern organizations have started to capitalize them, through a strategic Human Resource Management, which is followed by a good Learning and Development System. It can create a culture of continuously enabling people, to grow as well as make the organization to grow. It is the main role player in accommodating change and gaining importance, for the organisational success and effectiveness.

\section{Purpose of the Study}

The purpose of the study was to know the impact of learning and development strategy, on organisational performance in UCO Bank.

\section{Research Objectives}

- To study the perception of the employees on learning and development.

- To study and analyze how learning and development strategy contributes towards enhancing the 
organization performance.

\section{LITERATURE REVIEW}

Jogaiah (1990), has presented an in-depth analysis of training and development of executives, in the Indian power sector. Apart from providing a strong theoretical and conceptual observation, on training and development of executives, it highlights on problems and prospects, concerning personnel policies. HRD policies and practices, relating to executive training and development and institutional training network, in the power sector.

Subbarao (1993), presented various developments in the HRM, in a comprehensive form. He attempted to look into the current trends, in the Human Resource function, with a view to outline the future development that is likely to take place in the years ahead. While discussing job analysis, job evaluation, employee benefits, recruitment and selection line, staff conflicts, social responsibility policies, etc., he has also analyzed the organizational culture and climate, organizational policies, organizational effectiveness, followership, participative management, dual career problems, qualify of work life, quality circles and organizational development in detail.

According to Larsson (1997), learning as the responsibility of the individual observing that, everyday life is enough in itself to produce a widening gap in knowledge, between those who choose to learn and those who do not. Even without educational intervention, learning will occur because; it is a part of every person's everyday life. Hence, provided employees take responsibility for their own learning, they could develop their education of the whole man, simply through their experience of work and life.

Brinkerhoff (1997), highlighted that, the unsupportive superior ignores, demotivates skills use or punishes employees, who are not going, to use the skills they have learned. The unsupported employee will continue to repeat old behaviours, resulting in manager and employers losing time on training.

Nequin and Bladwin (2003), emphasized the importance of Management and the trainee's immediate supervisor, in providing pre-programme support and thus, facilitating post programme transfer of learning.

Saraswathi (2010), said that, in most Indian organizations, the normal practice is to promote people, on the basis of past performance. She argues that, most young executives joining organizations are career minded, ambitious and looking for fast growth.

According to Appah et al. (2011), organizations all over the world, invest several millions on recruitment, selection, training and development, promotions, transfers and compensation of human resources, for the performance of their respective organizations. Human beings are the active agents, who accumulate wealth, exploit material resources, build social, economic and political organizations, and carry forward national development. Clearly, a nation that is unable to develop the skills and knowledge of its people, and to utilize them efficiently in the national economy, will be unable to develop anything else.

Bartlett (2001), found a positive relationship between training and organizational commitment and recommended that, human resource development professionals adapt new research methods, to demonstrate to organizational decision makers that, training and development contributes to desired workplace attitudes, which may in turn influence behaviours such as, absenteeism and turnover.

According to Schmidt (2007), Training is one of the most important functions that directly contribute to the 
development of human resource. Training is a set of planned activities, on the part of an organization to increase the job knowledge and skills, or to modify the attitudes and social behaviour of its members, in ways consistent with the goals of the organization and the requirement of the job.

Lawrence S. Kleiman, defines training and development as a planned learning experience, designed to provide workers with competencies, needed to perform their current or future job. Employees are trained on the job or through special in-house training programmes. An outside training may be utilized, to enhance, update or develop specific skill of the employees. In the development of HR, training and development functions are combined together, for developing skills as well as basic aptitudes, leading to continued personal growth. It includes training of employees, to perform their jobs and retaining of employees as their job requirements change. Encouraging the development and growth of more effective employees is another facet.

\section{Theoretical Framework of the Study}

Human Resource is considered as the most important resource, for organisation success in the modern world. Dynamic and competent people can build dynamic organisation, or make the things happen, to achieve the organizational goal. Therefore, the organizations need to ensure that, competent of the employees remain at high levels. It is a continuous process, to ensure the development; it can build employees competencies, which include skill and attitude. It can make them dynamic, motivated and effective in achieving the goal. In today's world, the organization competency is nothing but people's competency. In challenging economic environment, the strategy for organisation sustenance and growth means, building people, who are competent to face the challenges of changing business world. So, it has become the first duty of the organisation's people's preparedness. In order to make people ready for organisation, change of training is the most important mechanism that needs to be very effective and fruitful.

Table 1

\begin{tabular}{|r|l|l|l|}
\hline \multicolumn{2}{|c|}{ Specific Purposes } & \multicolumn{2}{|l|}{} \\
\hline$\bullet$ & Increased productivity & & \\
\hline$\bullet$ & Improved quality & & \multicolumn{2}{|l|}{$\begin{array}{l}\text { Overall } \\
\text { purpose } \\
\text { Increased } \\
\text { organizational } \\
\text { effectiveness }\end{array}$} \\
\hline$\bullet$ & Higher Morale & & \\
\hline$\bullet$ & Enlarge indirect compensation & & \\
\hline$\bullet$ & Heightened obsolescence prevention & & \\
\hline$\bullet$ & Enhanced personal growth & & \\
\hline
\end{tabular}

\section{UCO Bank}

UCO Bank is a commercial bank, established in 1943. The idea to establish the bank was first conceived by G. D. Birla, the famous industrialist, after the historic 'Quit India Movement' in 1942. The idea was culminated on the 6th of January 1943, when The United Commercial Bank Ltd. was born, with its Registered and Head Office at Kolkata. A commercial bank and a Government of India Undertaking, it comprises of government representatives, as well as 
renowned professionals like accountants, management experts, economists, businessmen, and so on, in its Board of Directors. United Commercial Bank has stretched out, two of all segments of the economy - be it agriculture, industry, trade and commerce, services or infrastructure. Along, with 13 other major commercial banks of India, United Commercial Bank was nationalized on 19th July, 1969, by the Government of India. Thereafter, the Bank expanded rapidly. To keep pace with the developing scenario and expansion of business, the Bank undertook an exercise, in organizational restructuring in the year 1972. Under the act of Indian Parliament, in 1985, its name changed from United Commercial Bank to the present name, UCO Bank. As of 2005, the bank has 2000 Service Units spread all over India. A distinctive feature of UCO bank is its introduction of 'NO HOLIDAY' branches. These bank branches, work on all the 365 days of a year. With the age of global banking, UCO bank has also changed to be adept, with the newest technology, boasting of specialized computerized branches, in both India and overseas.

\section{Branches \& ATM Services}

Headquartered in Kolkata, UCO Bank has about 35 Regional Offices spread all over India. Overseas, it has two branches, in Singapore and Hong Kong. UCO bank has a total of 414 ATMs across the states of Andhra Pradesh, Assam, Bihar, Chattisgarh, Chandigarh, Goa Gujarat, Haryana, Himachal Pradesh, Jharkhand, Karnataka, Kerala, Madhya Pradesh, Maharashtra, Meghalaya, Nagaland, New Delhi, Orissa, Pondicherry, Punjab, Rajasthan, Sikkim, Tamil Nadu, Tripura, Uttar Pradesh and West Bengal.

\section{Products \& Services}

- $\quad$ NRI Banking

- Foreign Currency Loans

- Finance/Services to Exporters

- Finance/Services to Importers

- Remittances

- Forex \& Treasury Services

- Resident Foreign Currency (Domestic) Deposits

- Correspondent Banking Services

- General Banking Services

\section{RESEARCH METHODOLOGY}

For the present study, a descriptive research design is adopted and accordingly, the sampling design is done. Data are collected from both primary and secondary sources. In order to collect the data from primary source, the questionnaire was used, whereas secondary data are collected from website of bank, annual reports, journals etc. Statistical package for social science (SPSS) is used, to analyse the data as per objectives and test like Mean, Standard Deviation and Regression are applied, to ascertain the result.

\section{Sample Size of the Study}


To achieve the objective of the research, 54 questionnaire were distributed among the employees of UCO Bank, at their training centre. The questionnaire was design on Likert 5 rating scale $(1=$ Strongly Disagree, $2=$ Disagree, $3=$ Neutral, 4= Agree, 5= Strongly Agree). To test the impact of the variables, the data were analysed through SPSS.

\section{ANALYSIS}

Table 2: Descriptive Statistics

\begin{tabular}{|l|c|c|c|c|c|}
\hline & N & Minimum & Maximum & Mean & Std. Deviation \\
\hline learn_dev & 54 & 2.83 & 4.67 & 4.0571 & .32931 \\
\hline orgn_perf & 54 & 3.60 & 4.90 & 4.2763 & .27205 \\
\hline Valid N (listwise) & 54 & & & & \\
\hline
\end{tabular}

\section{Regression}

Table 3: Model Summary

\begin{tabular}{|l|c|c|c|c|}
\hline Model & R & R Square & Adjusted R Square & Std. Error of the Estimate \\
\hline 1 & $843^{\mathrm{a}}$ & 711 & 705 & 14770 \\
\hline
\end{tabular}

a. Predictors: (Constant), learn_dev

b. Dependent Variable: orgn_perf

Table 4: Coefficients ${ }^{\mathrm{a}}$

\begin{tabular}{|c|l|c|c|c|c|c|}
\hline \multirow{2}{*}{ Model } & \multicolumn{2}{|c|}{$\begin{array}{c}\text { Unstandardized Coefficients } \\
\text { Standardized } \\
\text { Coefficients }\end{array}$} & \multirow{2}{*}{ t } & \multirow{2}{*}{ Sig. } \\
\cline { 3 - 7 } & Beta & & \\
\hline \multirow{2}{*}{1} & (Constant) & 1.451 & 251 & & 5.785 & 000 \\
\cline { 2 - 7 } & learn_dev & 696 & 062 & 843 & 11.305 & 000 \\
\hline
\end{tabular}

a. Dependent Variable: orgn_perf

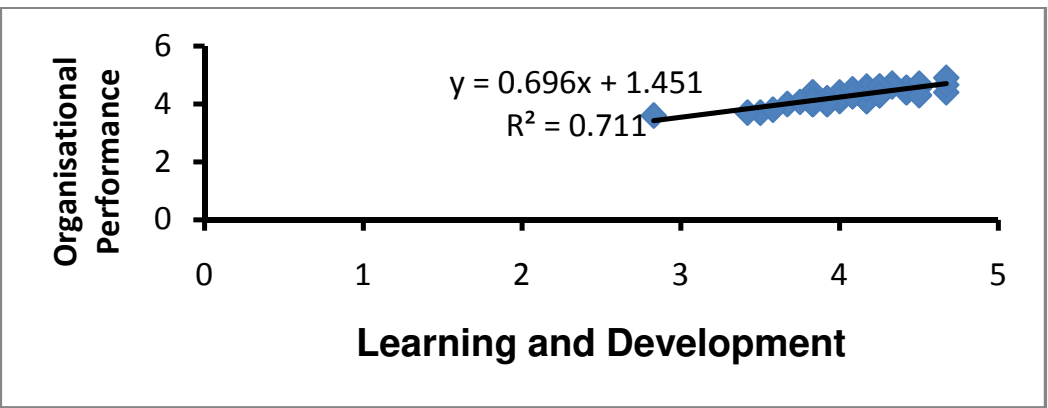

\section{Findings}

The data was collected from despondence of UCO Bank. After applying the regression on the collected data, to analyse the impact of learning and development (Independent Variable) and organisational performance (Dependent Variable), the above mentioned result has been drawn, where mean of learning and development was found as 4.057 and mean of organisational performance is 4.276 and standard deviation is 0.329 and 0.272 , respectively. That reflects positive perception of employees, towards learning and development. The regression result shows, $\mathrm{Y}=0.696 \mathrm{x}+1.451$ and $\mathrm{R}=0.843$, 
$\mathrm{R}$ square is 0.711 and adjusted $\mathrm{R}$ square is 0.705 . So, the independent variable of the study learning and development has significant relationship, with dependent variables of the study i.e. Organisational Performance. The unstandardized value of mentioned table shows that, independent variable learning and development has a positive impact on organisational performance, in this study.

\section{CONCLUSIONS}

An overview of literature and from the study it is revealed that, learning and development system is indispensable for organisation, to be competitive and to accommodate the change. It acts as a supportive corporate strategy, to march ahead. It is a very critical factor for service organisation, where behavioural factor considerations are more important for business growth. The ultimate goal of organisation is, to improve the quality of life of its entire people. Therefore, the purpose of the study was, to find out the impact of learning and development strategy on organisational performance. It shows the positive relation between learning and development strategy, on organisational performance.

\section{REFERENCES}

1. Appah, E., Coleman, A. and Buseni, J. (2011). "Disclosure of human resource value in the balance sheet of organizations". Int. J. Labour Organ. Psychol., 5(1\&2), PP 1-10.

2. Bartlett, K. R. (2001). The relationship between training and organisational commitment: A study in the health care field. Hum. Resour. Dev. Quart., 12(4): PP 335-352.

3. Brinkerhoff, R. (1997). Are you expecting enough from Training? Self Management Institute special Report, retrieved, 1997.

4. Jogaiah, T. (1990). Training and Development of executive, Frontier of Management Science.

5. Larsson, S. (1997). “The meaning of life-long learing”, in S. Walters (ed.) Globalization, Adult Education and Training: impacts and issues, London: Zed Books.

6. Laguo Livingstone Gilbert et al., Hybrid Leading Organisational Performance in Nigeria: Exploring Leader -Member Exchange $(L M X)$ and Followership Participation, International Journal of Business Management \& Research (IJBMR), Volume 3, Issue 3, July - August 2013, pp. 33-44

7. Naquen, S. S. and Baldwin, T. T. (2003), Manager Transfer Before Learning Begins. The Transfer-Ready Learner' in E. F. Holton III T. T. Baldwin improving learning Transfer in organization, Santarscisco, CA; Jossey-Bass.

8. Saraswathi, S. (2010). Human resources development climate: An empirical study. Int. J. Innovat. Manage. Technol., 1(2): PP 174-179.

9. Schmidt, S. W. (2007). The relationship between satisfaction with workplace training and overall job satisfaction. Hum. Resour. Dev. Quart., 18(4): PP 481-498.

10. William Mills Abbey, Godfred Owusu-Bempah \& Isaac Owusu, Assessing the Relationship between Supply Chain Management and Organisational Performance in the Filtered Water Industry in Ghana, International Journal of Business Management \& Research (IJBMR), Volume 3, Issue 5, November - December 2013, pp. 97-108

11. Subba Rao, P. (1993). Human Resource Management Discovery publishing House, New Delhi. 


\section{APPENDIX}

Impact of Learning and Development Strategy on Organizational Performance

\begin{tabular}{|c|c|c|c|c|c|c|}
\hline \multirow[b]{2}{*}{ Sl. No. } & \multirow[b]{2}{*}{ Questions } & \multicolumn{5}{|c|}{ Tick $(\sqrt{ })$ in suggested box } \\
\hline & & $\begin{array}{l}\text { Strongly } \\
\text { Disagree } \\
\text { (1) }\end{array}$ & $\begin{array}{l}\text { Disagree } \\
\text { (2) }\end{array}$ & $\begin{array}{l}\text { Neutr } \\
\text { al } \\
(3)\end{array}$ & $\begin{array}{l}\text { Agree } \\
\text { (4) }\end{array}$ & $\begin{array}{l}\text { Strongly } \\
\text { Agree } \\
\text { (5) }\end{array}$ \\
\hline 1 & $\begin{array}{l}\text { Employees enhancement come through } \\
\text { Training \& Development }\end{array}$ & & & & & \\
\hline 2 & $\begin{array}{l}\text { Training and Development brings positive } \\
\text { attitude in employees }\end{array}$ & & & & & \\
\hline 3 & $\begin{array}{l}\text { With training and development job knowledge } \\
\text { increase in employees. }\end{array}$ & & & & & \\
\hline 4 & $\begin{array}{l}\text { Training and development teach the technique } \\
\text { of performing a job to employees }\end{array}$ & & & & & \\
\hline 5 & $\begin{array}{l}\text { Training and development enhance the skills } \\
\text { of job of employees }\end{array}$ & & & & & \\
\hline 6 & $\begin{array}{l}\text { Most of the employees consider training and } \\
\text { development vital for job }\end{array}$ & & & & & \\
\hline 7 & $\begin{array}{l}\text { Most of the employers consider training and } \\
\text { development waste of time and waste of } \\
\text { money }\end{array}$ & & & & & \\
\hline 8 & $\begin{array}{l}\text { Most of the employers give training to their } \\
\text { employees }\end{array}$ & & & & & \\
\hline 9 & $\begin{array}{l}\text { Training and development is essential for } \\
\text { employees }\end{array}$ & & & & & \\
\hline 10 & $\begin{array}{l}\text { Competency level of employees increases due } \\
\text { to Training \& Development }\end{array}$ & & & & & \\
\hline 11 & $\begin{array}{l}\text { Training and development boost up the morale } \\
\text { of the employees }\end{array}$ & & & & & \\
\hline 12 & $\begin{array}{l}\text { Training and development reduce the stress of } \\
\text { the employees }\end{array}$ & & & & & \\
\hline 13 & $\begin{array}{l}\text { Skilled employees performance and } \\
\text { productivity is more than the unskilled } \\
\text { employees }\end{array}$ & & & & & \\
\hline 14 & $\begin{array}{l}\text { Performance and productivity increase due to } \\
\text { the ability of the employees }\end{array}$ & & & & & \\
\hline 15 & $\begin{array}{l}\text { Performance and productivity increase due to } \\
\text { the enhanced competency of the employees }\end{array}$ & & & & & \\
\hline 16 & $\begin{array}{l}\text { High morale employees give better } \\
\text { performance }\end{array}$ & & & & & \\
\hline 17 & $\begin{array}{l}\text { Performance and productivity increase due to } \\
\text { the job knowledge }\end{array}$ & & & & & \\
\hline 18 & $\begin{array}{l}\text { Performance and productivity increase due to } \\
\text { the technique of job }\end{array}$ & & & & & \\
\hline
\end{tabular}


Table Contd.,

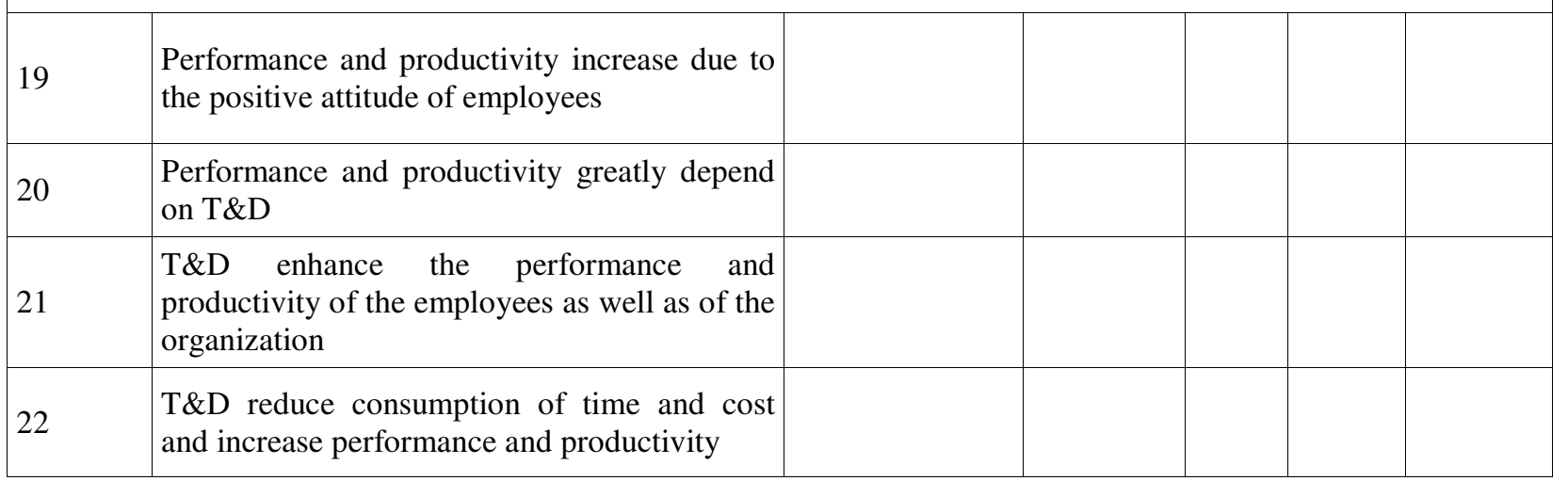

